\title{
Mid-term results of calcaneal plating for displaced intraarticular calcaneus fractures
}

\author{
Eklemiçi kalkaneus kırıklarında cerrahi tedavi yöntemimizin \\ orta dönem sonuçları
}

\author{
Deniz GÜLABİ, ${ }^{1}$ Ferdi SARI, ${ }^{1}$ Cengiz ŞEN, ${ }^{2}$ Cem Coşkun AVCI, ${ }^{1}$ \\ Fevzi SAĞLAM, ${ }^{1}$ Mehmet ERDEM, ${ }^{1}$ Güven BULUT ${ }^{1}$
}

\section{BACKGROUND}

The radiological and functional results of surgical treatment in intraarticular calcaneal fractures are presented in this study.

\section{METHODS}

27 feet of 26 patients with displaced intraarticular fractures were treated surgically in our clinic between November 2003 and May 2009. Twenty-one patients were male (81\%), and 5 were female (19\%). The average age was 29.2 (range, 18-61 years) at the time of the surgical treatment. Open reduction internal fixation was performed by using a calcaneal plate.

\section{RESULTS}

The results were evaluated according to the Maryland foot scores and Creighton-Nebraska scores. The mean follow-up period was 34.4 months (range, 19-85 months). The radiological evaluation was made according to the mean value changes of Böhler and Gissane angles after injury and at the last follow-up. Except for 3 patients with Sanders type 4 fractures, good results were obtained with surgical treatment.

\section{CONCLUSION}

We conclude that open reduction and internal fixation methods yield a reasonable outcome, even in patients with Sanders type 4 intraarticular fractures of the calcaneus.

Key Words: Calcaneal plating; calcaneus fracture; intraarticular fracture; Sanders classification.
$\boldsymbol{A M A C}$

Kalkaneus kırıklarında cerrahi tedavi sonuçlarımız radyolojik ve fonksiyonel açıdan değerlendirildi.

\section{GEREC VE YÖNTEM}

Kasım 2003 - Mayıs 2009 tarihleri arasında kliniğimizde deplase intraartiküler kırığı olan 26 hastanın 27 ayağ çalışmaya alındı. Hastaların 21'i erkek (\%81), 5'i kadın (\%19) ve ameliyat olduklarında ortalama yaşları 29,2 (18-61) idi. Kalkaneus plağı kullanılarak açık redüksiyon ve internal tespit kullanıldı.

\section{BULGULAR}

Hastalar Maryland ve Creighton-Nebraska ayak değerlendirme skorlarına göre değerlendirildi. Radyolojik değerlendirme Böhler ve Gissane açılarındaki değişikliklere göre yapıldı. Hastalar ortalama 34,4 ay (dağılım, 6-79 ay) takip edildi. Üç hasta dışında diğer hastalarda iyi ve çok iyi sonuç elde edildi.

\section{SONUC}

Sanders tip 4 kırığı olan hastalarda tatmin edici sonuçlar elde ettiğimiz için, bu tip kırıklarda bile açık redüksiyon internal tespit uygulamasının makul bir seçenek olduğu kanısindayiz.

Anahtar Sözcükler: Kalkaneus plakları; kalkaneus kırıkları; eklemiçi kırıklar; Sanders sınıflaması.

\footnotetext{
${ }^{1}$ Department of Orthopaedic and Traumatology, Dr. Lutfi Kırdar Kartal Training and Research Hospital, Istanbul; Faculty of Medicine, Istanbul, Turkey.
}

${ }^{1}$ Dr. Lütfi Kurdar Kartal Eğitim ve Arastırma Hastanesi, Ortopedi ve Travmatoloji Kliniği, İstanbul; ${ }^{2}$ Bezmi Alem Üniversitesi Tıp Fakültesi Ortopedi ve Travmatoloji Anabilim Dalı, İstanbul. 
Calcaneus fractures occur due to high-energy traumas such as falls from height and traffic accidents. These fractures are very important in socioeconomic terms as well, as they deprive $20 \%$ of the patients from returning to their jobs completely for up to three to five years following injury..$^{[1-3]}$

Calcaneus fractures comprise $2 \%$ of all the fractures, and they are the most common fractures among the tarsal bone fractures. Intraarticular calcaneus fractures comprise $75 \%$ of all the calcaneus fractures. ${ }^{[3,4]}$ Another important point to note is that the forces that cause the calcaneus fracture also injure the surrounding tissues to some extent.

While some authors suggest that the best results are obtained by surgical methods (open reduction and internal fixation, subtalar arthrodesis or percutaneous screw fixation), others advocate a conservative treatment method. ${ }^{[2,5-9]}$ In this study, we present the midterm results of open reduction internal fixation for the treatment of intraarticular calcaneal fracture. Our aim is to determine the success rate of our open reduction and internal fixation for intraarticular calcaneus fractures according to Maryland and Creighton-Nebraska foot scores. ${ }^{[10]}$

\section{MATERIALS AND METHODS}

Twenty-six patients with 38 displaced fractures were surgically treated between November 2003 and May 2009. Ten were excluded due to lack of followup, which left the study group of 26 patients with 27 displaced intraarticular calcaneus fractures. Twentyone patients were male $(81 \%)$, and five patients were female (19\%), and their average age was 29.2 years (18-61 years) when they were operated. Nineteen patients had isolated left, six patients had isolated right, and one patient had bilateral intraarticular calcaneus fractures. The reason for injury was fall from height in all patients.

Nine patients displayed accompanying injuries: Thoracic vertebral compression fractures in two patients, and radial head, glenoid, cuboid, second metatarsal, pilon tibia, lumbar burst, occipital, subtrochanteric, tibial plateau, sacrum, lateral mallolar, and pubic rami fracture in one patient each. Additionally, six patients exhibited contralateral calcaneal fractures without articular displacement, which were treated conservatively.

Anteroposterior, lateral, and tangential radiographs and computed tomography were obtained in all patients prior to surgical treatment. Decision-making and planning of the surgical treatment of the patients were undertaken according to the Sanders classification during evaluation of the computed tomography (Table 1).
The time interval from trauma to surgery was eight days on average (4-22 days). One patient, who was operated late on the 22nd day, had been followed up by the brain surgery clinic for 17 days due to head trauma and was then referred to our clinic. A plaster brace and immobilization and elevation were applied until the operation date.

Twenty-seven calcanei of 26 patients were operated, and extended lateral incision was used in all patients. Sherman reconstruction plates were used in 18 patients and Sanders anatomic calcaneus plates in 9 calcanei. Bone grafting was performed in all patients (autogenous iliac bone grafts in 18 and allografts in 8) (Table 1).

\section{Surgical technique}

The patient was placed on a radiolucent table in the lateral decubitis position so that the fractured extremity would face upwards. In patients who consented to autogenous iliac grafting, the ipsilateral iliac wing was also prepared sterile. The extended lateral incision was used in all patients. The fractured lateral wall was lifted with the help of an osteotome, followed by reduction of the sustencalum calcanei, anterior process, tuberosity and then the posterior facet. Once the correction was checked with the c-arm and found to be accurate, bone grafting was utilized into the defect in the calcaneal body and then internal fixation was performed using a plate (Figs. 1a to d, Figs. 2a to c). Active ankle and foot range-of-motion exercises were initiated on day 2 . The same day, patients were mobilized with crutches if not contraindicated due to an associated injury, without weight-bearing. At 15 days postoperatively, the sutures were removed and the posterior splint was discharged. The patients were allowed to bear weight by an average of 10.4 weeks (9-13 weeks) after the surgical treatment. All patients were evaluated according to the Maryland foot score and Creighton-Nebraska score on their last follow-up day.

\section{RESULTS}

The average follow-up time was 34.4 months (19-85 months). Twelve fractures were Sanders type $2(44.5 \%), 10$ were type $3(37 \%)$ and 5 were type 4 (18.5\%). According to Maryland foot score, very good results were obtained in 6 patients $(22.2 \%)$ and good results in 4 patients $(14.9 \%)$ in Sanders type 2 fractures; good results were obtained in 9 patients $(33.3 \%)$ and average results in 3 feet of 2 patients $(11.1 \%)$ in Sanders type 3 fractures; good results were obtained in 2 patients $(7.4 \%)$ and average results in 3 patients $(11.1 \%)$ in Sanders type 4 fractures. The patients' scores were obtained at the last follow-up.

According to the Creighton-Nebraska score, very good results were obtained in 7 patients $(26 \%)$ and good results in 3 patients (11\%) in Sanders type 2 
Table 1. Patients characteristics

\begin{tabular}{|c|c|c|c|c|c|c|c|c|c|}
\hline No & $\begin{array}{l}\text { Fracture } \\
\text { type }\end{array}$ & $\begin{array}{l}\text { Graft } \\
\text { type }\end{array}$ & $\begin{array}{l}\text { Maryland } \\
\text { score }\end{array}$ & $\begin{array}{c}\text { Creighton-Nebraska } \\
\text { score }\end{array}$ & $\begin{array}{l}\text { Böhler } \\
\text { injury }\end{array}$ & $\begin{array}{l}\text { Böhler last } \\
\text { follow-up }\end{array}$ & $\begin{array}{l}\text { Gissane } \\
\text { injury }\end{array}$ & $\begin{array}{l}\text { Gissane last } \\
\text { follow-up }\end{array}$ & $\begin{array}{l}\text { Plate } \\
\text { type }\end{array}$ \\
\hline 1 & $2 \mathrm{~A}$ & $\mathrm{CA}$ & Very good & Very good & 11.32 & 28.6 & 130.32 & 104.2 & Sanders \\
\hline 2 & $2 \mathrm{~A}$ & $\mathrm{CA}$ & Very good & Very good & 6.2 & 29.4 & 129.25 & 103.4 & Scherman \\
\hline 3 & $2 \mathrm{~A}$ & CA & Very good & Very good & 11.13 & 27.2 & 128.42 & 104.1 & Scherman \\
\hline 4 & $2 \mathrm{~A}$ & $\mathrm{CA}$ & Very good & Very good & 15 & 30 & 131 & 105 & Sanders \\
\hline 5 & $2 \mathrm{~A}$ & $\mathrm{CA}$ & Very good & Very good & 10.22 & 29.4 & 126.12 & 103.1 & Scherman \\
\hline 6 & $2 \mathrm{~A}$ & CA & Very good & Very good & 10.07 & 29.2 & 124.4 & 102.2 & Scherman \\
\hline 7 & $2 \mathrm{~B}$ & $\mathrm{CA}$ & Good & Good & 6.7 & 18 & 120.22 & 100.1 & Sanders \\
\hline 8 & $2 \mathrm{~B}$ & $\mathrm{CA}$ & Good & Very good & 10.1 & 28.7 & 127.8 & 99.2 & Scherman \\
\hline 9 & $2 \mathrm{~B}$ & $\mathrm{IC}$ & Good & Good & 9.2 & 27 & 119 & 99.4 & Scherman \\
\hline 10 & $2 \mathrm{C}$ & IC & Good & Good & 8 & 28 & 121.48 & 99.1 & Sanders \\
\hline 11 & $2 \mathrm{C}$ & IC & Intermediate & Good & 5 & 26.54 & 120 & 99 & Scherman \\
\hline 12 & $2 \mathrm{C}$ & IC & Intermediate & Good & 10.1 & 27 & 125.35 & 101.72 & Scherman \\
\hline 13 & $3 \mathrm{AB}$ & ICC & Good & Good & 9.2 & 24.4 & 125.6 & 99 & Scherman \\
\hline 14 & $3 \mathrm{AB}$ & ICC & Good & Good & 8.4 & 23.8 & 131 & 103.2 & Sanders \\
\hline 15 & $3 \mathrm{AB}$ & ICC & Good & Good & 9.2 & 24.2 & 133 & 98 & Scherman \\
\hline 16 & $3 \mathrm{AB}$ & ICC & Good & Good & 10 & 24.2 & 132.5 & 99.2 & Scherman \\
\hline 17 & $3 \mathrm{AC}$ & ICC & Good & Good & 6.8 & 27 & 125 & 110 & Scherman \\
\hline 18 & $3 \mathrm{AC}$ & ICC & Good & Good & 7.4 & 23.3 & 134.2 & 102.5 & Scherman \\
\hline 19 & $3 \mathrm{BC}$ & ICC & Good & Good & 8.2 & 24.8 & 133.4 & 99.1 & Sanders \\
\hline 20 & $3 \mathrm{BC}$ & ICC & Good & Intermediate & 3 & 22 & 140 & 102.6 & Scherman \\
\hline 21 & $3 \mathrm{BC}$ & ICC & Good & Intermediate & 7.1 & 24.3 & 131.3 & 99 & Scherman \\
\hline 22 & $3 \mathrm{BC}$ & ICC & Intermediate & Intermediate & 6.3 & 19 & 129.7 & 105.9 & Sanders \\
\hline 23 & 4 & ICC & Good & Intermediate & 4 & 14 & 141.2 & 116 & Scherman \\
\hline 24 & 4 & ICC & Good & Intermediate & 3.7 & 19 & 140.6 & 97 & Scherman \\
\hline 25 & 4 & ICC & Intermediate & Intermediate & 2.3 & 12 & 140.2 & 111 & Sanders \\
\hline 26 & 4 & ICC & Intermediate & Intermediate & 1.5 & 13 & 138 & 106 & Sanders \\
\hline 27 & 4 & ICC & Intermediate & $\mathrm{Bad}$ & 0 & 12 & 145 & 118 & Scherman \\
\hline
\end{tabular}

CA: Cancalleous allograft; IC: Iliaca cancalleous; ICC: Ilaca corticocancalleous.

fractures; good results were obtained in 7 patients $(26 \%)$ and average results in 5 feet of 4 patients $(18 \%)$ in Sanders type 3 fractures; average results were obtained in 4 patients $(15 \%)$ and poor results in 1 patient $(4 \%)$ in Sanders type 4 fractures (Table 1$)$.

The change in Böhler and Gissane angles is shown in Table 1. At the last follow-up, the mean Böhler angle was improved $15.9^{\circ}$ with Sanders plate, $19.05^{\circ}$ with Sherman plates and Gissane angle was improved $23.65^{\circ}$ with Sanders plate, $23.27^{\circ}$ with Sherman plates in Sanders type 2 fractures; Böhler angle was improved $14.9^{\circ}$ with Sanders plate, $16.7^{\circ}$ with Sherman plates, and Gissane angle was improved $28.63^{\circ}$ with Sanders plate, $30.13^{\circ}$ with Sherman plates in Sanders type 3 fractures; Böhler angle was improved $10.6^{\circ}$ with Sanders plate, $12.5^{\circ}$ with Sherman plates, and Gissane angle was improved $30.6^{\circ}$ with Sanders plate, $31.93^{\circ}$ with Sherman plates in Sanders type 4 fractures.

Four patients developed superficial soft tissue infection during the postoperative period, which responded to oral antibiotic treatment and wound care. Small skin necrosis was encountered in two patients, which resolved completely with local wound care without the need for a reconstructive procedure.

\section{DISCUSSION}

Calcaneus fractures comprise $2 \%$ of all fractures, and $60-75 \%$ of these fractures are intraarticular. Ten percent of the patients with calcaneus fractures have accompanying spine fractures and other extremity injuries. Similar proportions were found in our study as well. Ninety percent of the calcaneus fractures occur in males employed in industry aged between 21 and 45 years, which demonstrates that these fractures have important economic impacts. ${ }^{[1]}$ Calcaneus fractures are generally due to high-energy traumas such as a fall from height and traffic accidents.

We used Sanders classification based on computed tomography for our patients; however, no classification system has proved adequate. ${ }^{[12]}$ Twelve of the 27 calcaneus fractures comprising our task group were found to be type 2, 10 were type 3 , and 5 were type 4 .

The options for treating intraarticular calcaneus fractures may be evaluated in four groups ${ }^{[1,13,14]}$ as: Conservative treatment, closed reduction percutaneous fixation, open reduction internal fixation and primary subtalar arthrodesis, and mini open approaches with percutaneous fixation. ${ }^{[15-17]}$ 

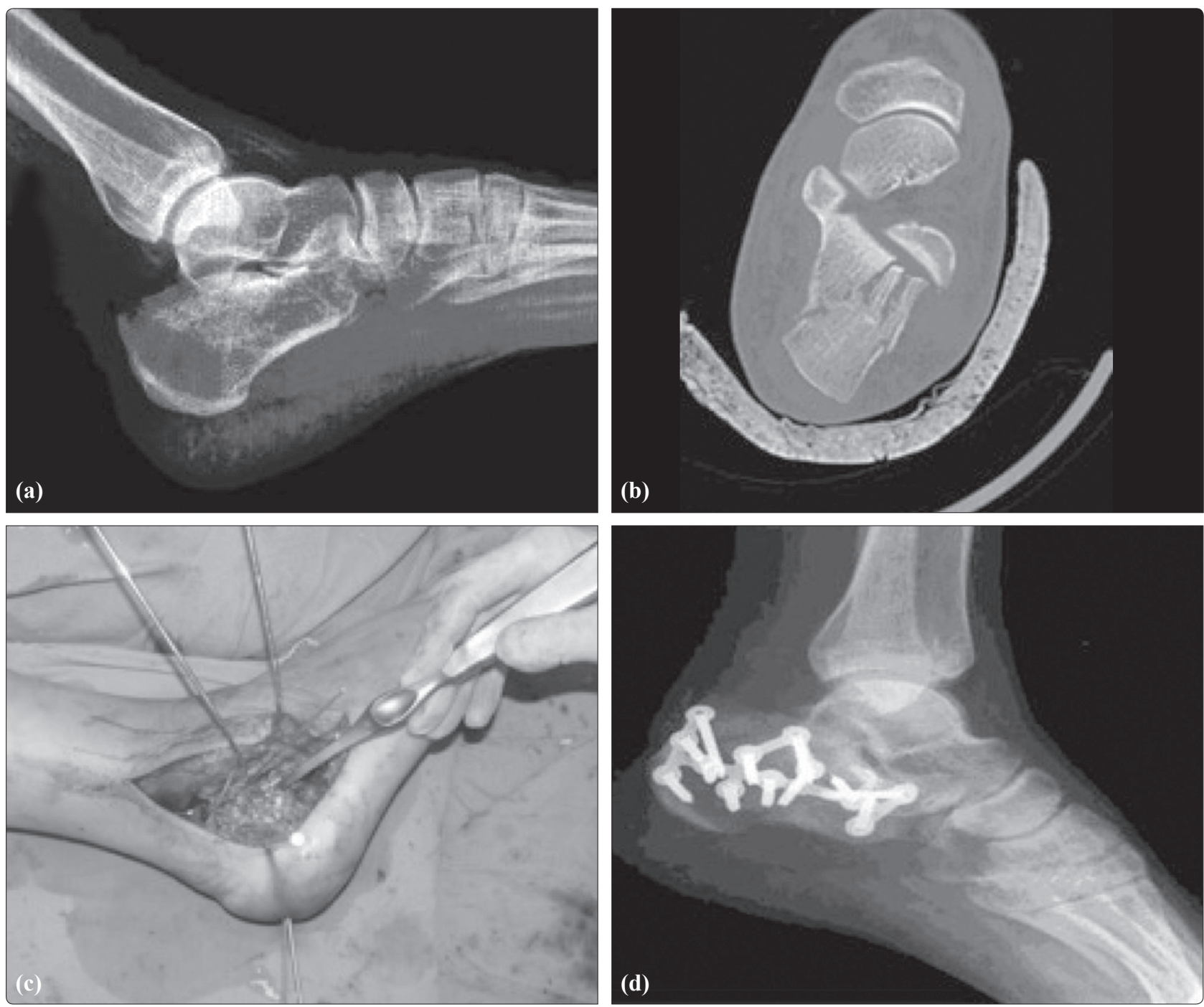

Fig. 1. (a) Right foot lateral radiography shows a displaced intraarticular calcaneal fracture in a 34-year-old man injured in a fall. (b) Preoperative CT scan shows Sanders type 3AB fracture. (c) Reduction obtained through lateral extended incision.

(d) Postoperative lateral radiography at 1-year follow-up.

Kitoaka et al. ${ }^{[8]}$ reviewed the results of the walking analyses of 16 of 27 patients, who were not subjected to reduction and were treated with plaster. Many patients in their study showed differences in walking especially on uneven grounds, which showed that conservative treatment of displaced calcaneus fractures results in permanent functional disorders, at least to some extent.

O'Farrel et al. ${ }^{[18]}$ treated 12 patients with surgical methods and 12 patients with conservative methods. They concluded that the surgical treatment was superior. Similarly, Leung et al. ${ }^{[19]}$ compared 44 patients treated by surgical methods with 19 patients treated conservatively according to the results of three-year follow-up on average. Comparing pain, ease of movement, return to job, and swallowed back of the foot, they found that the results of the group treated surgically were significantly better.
For patients who are to undergo surgical treatment, the timing of the operation is very important. While many authors suggest that the surgical intervention take place after the excessive edema in the foot has regressed, there are also authors suggesting it take place within the first 24 hours. Surgical intervention should preferably take place after regression of the excessive edema and should not be delayed beyond two weeks, as it will be difficult to provide anatomic reduction. ${ }^{[1,20,21]}$ The period between injury and operation was eight days on average in our cases. One patient was operated on day 22 , as the patient was admitted and followed up by the brain surgery clinic. We agree that the surgical intervention should take place once the edema in the foot has regressed.

Many of the studies published recently about the surgical treatment of calcaneus fractures use the lateral approach, in which the reduction of the calcaneus body 
and calcaneus height, length and width can be regained regardless of the disintegration level. ${ }^{[12,22]}$ Extended lateral incision was used for 26 ankles out of 27 operated (96\%), and medial incision was used for $1(4 \%)$. When the literature is reviewed, good and perfect results were obtained only for displaced intraarticular calcaneus fractures for which the lateral approach was used. ${ }^{[12,22-25]}$ It is preferred by many surgeons at present, as it provides wide lateral incision, and whole lateral wall, subtalar joint and calcaneocuboid joint visualization, and leads to nearly no peroneal tendon or sural nerve damage, but poses high skin necrosis risk. ${ }^{[26]}$ Extended lateral incision was used for all our patients.

The osteosynthesis material should be selected to provide a stable fixation and should allow early movement of the ankle and subtalar joint. ${ }^{[25,27]}$ We used Sherman plates in 18 patients and Sanders calcaneus plate in 9 patients. Sherman plates were preferred at first, and Sanders plates later. We did not observe any reduction loss in the early or late period due to osteosynthesis material. Therefore, it is our opinion that osteosynthesis by plate screw is very important in receiving good functional results by both protecting the anatomic reduction and enabling early movement.

Use of bone grafting remains controversial for the treatment of calcaneus fractures. While many authors suggest that the calcaneus with cancellous structure will recover fast and there is thus no need to use bone grafting, there are also authors suggesting that bone grafting should absolutely be used in order to protect joint reduction, and also that the bone graft can add mechanical strength and stimulate fracture healing. [1,28-30] We used autografting in 18 cases and allografting in 8 cases in order to preserve calcaneus integrity and to support subtalar joint reduction due to bone defects. We did not face any problems with these patients and indeed obtained good results. It is our opinion that it is beneficial to use bone grafting in order to preserve joint reduction for displaced intraarticular calcaneus fractures as bone defect develops following reduction.

There is no consensus regarding surgical maintenance and rehabilitation of the intraarticular fractures, just as there is no such consensus about their treatment. ${ }^{[31,32]}$ There are those who prefer fixation by plaster for two to three weeks following surgery, while others have the patient start on early active movements on day $2 .{ }^{[14]}$ We had our patients start active ankle and foot movements after receiving the drain on day 2 . We introduced the patients to partial weight-bearing in weeks 7-8 and introduced full weight-bearing in weeks 9-12. We recommend starting active motion during the early period, on day 2 , if stable osteosynthesis is ensured.

The key to success in the surgical treatment of intraarticular calcaneus fractures is ensuring reduction.
In cases with no ensured anatomic reduction, heel and calcaneofibular impingement pain is common during the early period, while arthritic complaints are common in the late period. In $4(80 \%)$ of our 5 patients operated due to Sanders type 4 fracture and 2 (16.6\%) of our 12 patients operated due to Sanders type 3 fracture, we determined subtalar arthritic changes. We suggested shoe modifications and made some other suggestions to these patients in the late follow-up period. The modificatation of the shoes were as follows: the posterior heel of the shoes is designed in the equinus posture with soft sole plate to decrease the pressure at the subtalar joint. After the modification of the shoes,
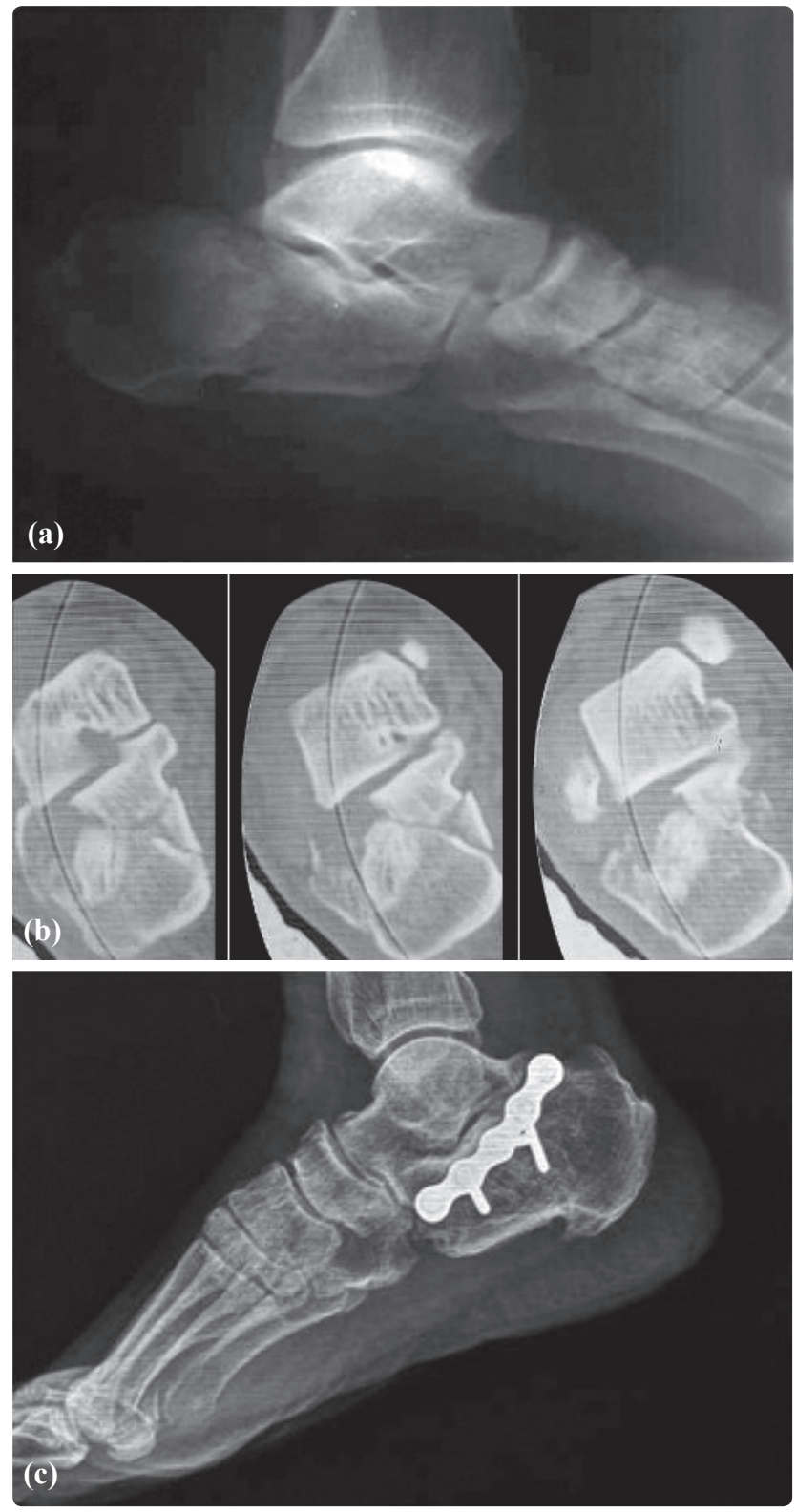

Fig. 2. (a) Right foot lateral radiography shows a displaced intraarticular calcaneal fracture in a 61-year-old man injured in a fall. (b) Preoperative CT scan shows Sanders type 2 fracture. (c) Postoperative lateral radiography at the 6-month follow-up. 
our patients were pleased, but there was no significant recovery in their Maryland and Creighton-Nebraska foot scores; they are all scheduled for an arthrodesis procedure in the future. The inversion and evertion motion of these patients were decreased.

In our study, we obtained very good results in 6 patients and good results in 15 patients according to the Maryland foot score, which yields a proportion of $77 \%$ for good and very good results. Anatomic reduction and stable osteosynthesis are very important to achieve good functional results in the early period and to enable the patients to return to their former jobs. Twenty-four of our patients returned to their former employment in an average period of 6.3 months. Some authors suggest trying anatomic reduction for type 4 fractures, while others suggest subtalar arthrodesis directly. ${ }^{[1,2,21]}$ It is our opinion that efforts should be made to enable reconstruction of the subtalar joint. In our study, 4 of 5 patients with type 4 fractures were working. Three of these patients $(75 \%)$ returned to their jobs in 10 months on average. We did not apply subtalar arthrodesis to our patients.

The most common complication faced following calcaneus fracture is related to wound healing. ${ }^{[26,33,34]}$ Risk factors for wound problems include smoking, diabetes, open fractures, high body mass index, and enclosing the skin in a single layer. Most of the scars heal eventually. In case of a wound problem, movement exercises are delayed in order to prevent any further disintegration. Plaster may be applied on the extremity by leaving a window over the scar and wet-to-dry dressing changes, or other granulation-stimulant scar agents may be started. ${ }^{[12,15]}$ In our study, 4 patients had a superficial wound infection that responded to oral antibiotics according to culture and sensitivity. The organism was Staphyloccocus epidermidis in all and it was sensitive to Bactrim.

Two patients $(8 \%)$ with skin necrosis were treated with daily wound care with no need for secondary intervention. The implants of one patient were removed due to plate irritation one year after the surgery.

The most common neurological complication following the treatment of calcaneal fractures is iatrogenic nerve injuries. The sural nerve is the nerve most affected, due to frequent use of lateral incision, and may be observed in up to $15 \%$ of the cases. In our study, temporary sural nerve hypoesthesia was observed in only one patient in the early period.

In light of both the knowledge available in the literature and our own experience, we conclude that open reduction and a stable fixation method yield more satisfactory results when compared to the conservative treatment methods in the treatment of displaced intraarticular calcaneus fractures. ${ }^{[34]}$
None of the authors received any kind of support related to this study.

\section{REFERENCES}

1. Sanders R. Fractures and fracture-dislocations of the calcaneus. In: Coughlin MJ, Mann RA, editors. Surgery of the foot and ankle. Vol. 2, 7th ed. St. Louis: Mosby; 1999. p. 1422-64.

2. Sanders R. Displaced intra-articular fractures of the calcaneus. J Bone Joint Surg Am 2000;82:225-50.

3. Potter MQ, Nunley JA. Long-term functional outcomes after operative treatment for intra-articular fractures of the calcaneus. J Bone Joint Surg Am 2009;91:1854-60.

4. Sayed-Noor AS, Agren PH, Wretenberg P. Interobserver reliability and intraobserver reproducibility of three radiological classification systems for intra-articular calcaneal fractures. Foot Ankle Int 2011;32:861-6.

5. Giachino AA, Uhthoff HK. Intra-articular fractures of the calcaneus. J Bone Joint Surg [Am] 1989;71:784-7.

6. Howard JL, Buckley R, McCormack R, Pate G, Leighton R, Petrie D, et al. Complications following management of displaced intra-articular calcaneal fractures: a prospective randomized trial comparing open reduction internal fixation with nonoperative management. J Orthop Trauma 2003;17:241-9.

7. Barnard L, Odegard JK. Conservative approach in the treatment of fractures of the calcaneus. J Bone Joint Surg [Am] 1955;37-A:1231-6.

8. Kitaoka HB, Schaap EJ, Chao EY, An KN. Displaced intraarticular fractures of the calcaneus treated non-operatively. Clinical results and analysis of motion and ground-reaction and temporal forces. J Bone Joint Surg [Am] 1994;76:153140.

9. Pozo JL, Kirwan EO, Jackson AM. The long-term results of conservative management of severely displaced fractures of the calcaneus. J Bone Joint Surg [Br] 1984;66:386-90.

10. Schepers T, Heetveld MJ, Mulder PG, Patka P. Clinical outcome scoring of intra-articular calcaneal fractures. J Foot Ankle Surg 2008;47:213-8.

11. de Souza LJ, Rutledge E. Grouping of intraarticular calcaneal fractures relative to treatment options. Clin Orthop Relat Res 2004;420:261-7.

12. Sanders R, Fortin P, DiPasquale T, Walling A. Operative treatment in 120 displaced intraarticular calcaneal fractures. Results using a prognostic computed tomography scan classification. Clin Orthop Relat Res 1993;290:87-95.

13. Aitken AP. Fractures of the os calcis-treatment by closed reduction. Clin Orthop Relat Res 1963;30:67-75.

14. Fractures and dislocations of the calcaneus. In: Rockwood Jr. CA, Green DP, Bucholz RW, Heckman JD, Fitzgibbons TC, McMullen ST, Mormino MA, editors. Fractures in adults. 5th ed. Vol. 2, Lippincott-Raven; 2001. p. 2133-79.

15. Frank MA, Berberian W, Liporace F. Calcaneal fractures: surgical exposure and fixation technique update. Current Orthopaedic Practice 2011;22:4-11

16. Weber M, Lehmann O, Sägesser D, Krause F. Limited open reduction and internal fixation of displaced intraarticular fractures of the calcaneum. J Bone Joint Surg Br 2008;90:1608-16.

17. Simpson RB. Fractures of the calcaneus. Curr Opin Orthop 2007;18:124-7.

18. O'Farrell DA, O'Byrne JM, McCabe JP, Stephens MM. Fractures of the os calcis: improved results with internal fixation. Injury 1993;24:263-5.

19. Leung KS, Yuen KM, Chan WS. Operative treatment of dis- 
placed intra-articular fractures of the calcaneum. Mediumterm results. J Bone Joint Surg Br 1993;75:196-201.

20.Zwipp H, Rammelt S, Gavlik JM. Calcaneus fractures. In: Surgical techniques in orthopaedics and traumatology. Paris: Elsevier SAS; 2000. p. 55-650-B, 7.

21. Sanders R, Gregory P. Operative treatment of intra-articular fractures of the calcaneus. Orthop Clin North Am 1995;26:203-14.

22. Sanders R, Fortin P, DiPasquale T, Walling A. Operative treatment in 120 displaced intraarticular calcaneal fractures. Results using a prognostic computed tomography scan classification. Clin Orthop Relat Res 1993;290:87-95.

23. Bèzes H, Massart P, Delvaux D, Fourquet JP, Tazi F. The operative treatment of intraarticular calcaneal fractures. Indications, technique, and results in 257 cases. Clin Orthop Relat Res 1993;290:55-9.

24. Johnson EE, Gebhardt JS. Surgical management of calcaneal fractures using bilateral incisions and minimal internal fixation. Clin Orthop Relat Res 1993;290:117-24.

25. Letournel E. Open treatment of acute calcaneal fractures. Clin Orthop Relat Res 1993;290:60-7.

26. Tomesen T, Biert J, Frölke JP. Treatment of displaced intraarticular calcaneal fractures with closed reduction and percutaneous screw fixation. J Bone Joint Surg Am 2011;9310:9208 .
27. Aşik M, Sen C. Surgical management of intraarticular fractures of the calcaneus. Arch Orthop Trauma Surg 2002;122:354-9.

28. Banerjee R, Nickisch F, Easley ME, Digiovanni CW. Foot injures. In: Browner BD, Jupiter JB, Levine AM, Trafton PG, Kretek C, editors. Skeletal trauma. Vol. 2, 4th ed. Philadelphia: Saunders; 2009. p. 2626-64.

29. Squires B, Allen PE, Livingstone J, Atkins RM. Fractures of the tuberosity of the calcaneus. J Bone Joint Surg [Br] 2001;83:55-61.

30. Clare MP, Lee WE 3rd, Sanders RW. Intermediate to longterm results of a treatment protocol for calcaneal fracture malunions. J Bone Joint Surg Am 2005;87:963-73.

31. Gaskill T, Schweitzer K, Nunley J. Comparison of surgical outcomes of intra-articular calcaneal fractures by age. J Bone Joint Surg [Am] 2010;92:2884-9.

32. Kwon JY, Diwan A, Susarla S. Effect of surgeon training, fracture, and patient variables on calcaneal fracture management. Foot Ankle Int 2011;32:262-71.

33. Emara KM, Allam MF. Management of calcaneal fracture using the Ilizarov technique. Clin Orthop Relat Res 2005;439:215-20.

34. Jiang SD, Jiang LS, Dai LY. Surgical treatment of calcaneal fractures with use of beta-tricalcium phosphate ceramic grafting. Foot Ankle Int 2008;29:1015-9. 